\title{
Biochemiczne i fizjologiczne aspekty rozkładu barwników chlorofilowych
}

\section{mgr Martyna Zalewska ${ }^{\varpi}$, prof. dr hab. Zbigniew Tukaj}

Katedra Fizjologii i Biotechnologii Roślin, Wydział Biologii, Uniwersytet Gdański, ul. Wita Stwosza 59, 80-308 Gdańsk, tel.: (58) 523-60-87,

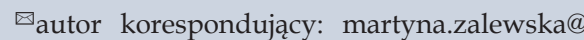
ug.edu.pl

https://doi.org/ 10.18388/pb.2019_261

Słowa kluczowe: chlorofil, rozkład chlorofilu, katabolity chlorofilu, rośliny wyższe, fitoplankton

Wykaz skrótów: AtMRP (ang. Arabidopsis thaliana multidrug resistance - associated protein) - białko oporności wielolekowej A. thaliana; Chlid $a$ - chlorofilid $a$; CLH (ang. chlorophyllase) - chlorofilaza; Cyklofeid $a$-enol - enolowa forma cyklofeoforbidu $a$; DNCC (ang. dioxobilin-type nonfluorescent chlorophyll catabolite) - dioksoniefluoryzujący katabolit chlorofilu; FCC (ang. fluorescent chlorophyll catabolite) - fluoryzujący katabolit chlorofilu; Feid $a-$ feoforbid $a$; Feo $a$ - feofityna $a$; hmFCC (ang. hypermodified fluorescent chlorophyll catabolite) - hiperzmodyfikowany katabolit chlorofilu; HCAR (ang. 7-hydroxymethylchlorophyll a reductase) - reduktaza 7-hydroksymetylochlorofilu a; Hv-NCC-1 (ang. Hordeum vulgare-nonfluorescent chlorophyll catabolite - 1) - najbardziej polarny niefluoryzujący katabolit chlorofilu $H$. vulgare; hydroksy- $p$ FCC - hydroksylowane wczesne fluoryzujące katabolity chlorofilu; NCC (ang. nonfluorescent chlorophyll catabolite) - niefluoryzujący katabolit chlorofilu; NOL (ang. nyc-1 like) - reduktaza chl $b$ A. thaliana; NYC1 (ang. non-yellow coloring-1) - reduktaza chlorofilu $b$ A. thaliana; $\mathrm{PaO}$ (ang. pheophorbide a oxygenase) - oksygenaza feoforbidu a; PDT (ang. photodynamic theraphy) - terapia fotodynamiczna; $p$ FCC (ang. primary fluorescent chlorophyll catabolite) - wczesny fluoryzujący katabolit chlorofilu; PiCC (ang. pink chlorophyll catabolite) - różowy katabolit chlorofilu; Pirofeid $a$ - pirofeoforbid $a$; Pirofeo $a$ - pirofeofityna $a$; PPH (ang. pheophytinase) feofitynaza; RCC (ang. red chlorophyll catabolite) - czerwony katabolit chlorofilu; RCCR (ang. red chlorophyll catabolite reductase) - reduktaza czerwonego katabolitu chlorofilu; RP-HPLC (ang. reverse phase-high performance liquid chromatography) - wysokosprawna chromatografia cieczowa w układzie faz odwróconych; SGR (ang. stay-green) - białko „stay-green”; TIC55 (ang. translocon at the inner chloroplast envelope 55) - translokon $55 \mathrm{w}$ wewnętrznej błonie chloroplastu; YCC (ang. yellow chlorophyll catabolite) - żółty katabolit chlorofilu

\section{STRESZCZENIE}

$\mathbf{P}_{\mathrm{f}}^{\mathrm{r}}$ ocesowi starzenia się liści i dojrzewania owoców towarzyszy rozkład chlorofilu do niefluorescencyjnych katabolitów (NCC). Ścieżkę rozpadu rozpoczynają reakcje redukcji w chloroplaście, w wyniku których cząsteczki chlorofilu $b$ przekształcane są do chlorofilu $a$. Następnie, specyficzna dechelataza i esteraza usuwają atom magnezu i łańcuch fitolu w wyniku czego powstaje feoforbid $a$. W kolejnym etapie oksygenaza feoforbidu $a$ oraz reduktaza czerwonego katabolitu dokonują otwarcia makropierścienia porfirynowego. Produktem tej przemiany jest wczesny fluorescencyjny katabolit ( $p$ FCC), który po hydroksylacji i innych specyficznych dla gatunku modyfikacjach trafia do wakuoli. W kwaśnym $\mathrm{pH}$ we wnętrzu tego organellum zachodzi izomeryzacja $p$ FCC do bezbarwnych NCC, końcowych produktów rozkładu chlorofilu u roślin wyższych. Brak jest nadal odpowiedzi na szereg pytań dotyczących losów i znaczenia milionów ton produktów rozpadu chlorofilu, corocznie uwalnianych w środowisku wodnym w wyniku obumierania komórek fitoplanktonu. Nieliczne doniesienia wskazują, że glony i cyjanobakterie mogą metabolizować swoje kluczowe barwniki fotosyntetyczne w podobny sposób do roślin wyższych, jednak do tej pory dokładny przebieg rozkładu chlorofilu u tych organizmów nie został poznany.

\section{WPROWADZENIE}

Chlorofile (Chl) to podstawowe barwniki umożliwiające przekształcanie energii świetlnej w wysokoenergetyczne związki na drodze fotosyntezy. Specyficzna budowa chemiczna, warunkująca ich wyjątkowe zdolności absorpcyjne sprawia, że funkcjonalne chlorofile, a także ich barwne prekursory i wczesne produkty rozpadu są potencjalnymi komórkowymi toksynami. Z tej przyczyny metabolizm zielonych barwników, który rocznie obejmuje około miliarda ton cząsteczek [1], podlega ścisłej regulacji na poszczególnych etapach rozwoju organizmów fotosyntetyzujących.

Synteza barwników chlorofilowych u roślin, glonów i cyjanobakterii jest bardzo dobrze poznana [2]. Badany od kilku dziesięcioleci i obecnie dokładnie opisany jest także katabolizm chlorofilu u roślin wyższych [3]. Niewiele wiadomo natomiast na temat rozpadu tych barwników u fotosyntetyzujących organizmów wodnych, chociaż ich udział w globalnej produkcji materii organicznej jest porównywalny do udziału roślin lądowych [4].

Niniejsza praca stanowi podsumowanie aktualnego stanu wiedzy na temat katabolizmu chlorofilu, ze szczególnym uwzględnieniem przemian zachodzących w organizmach wodnych.

\section{SZLAK DEGRADACJI CHLOROFILU U ROŚLIN WYŻSZYCH - ŚCIEŻKA OKSYGENAZY FEOFORBIDU $a$}

Przez wiele lat rozkład barwników chlorofilowych pozostawał oczywistym, choć niewyjaśnionym fenomenem przyrody. Jedną z głównych przyczyn początkowych niepowodzeń w ustaleniu losów chlorofilu w żółknących tkankach było przeświadczenie, że katabolizm tego związku prowadzi do powstania barwnych produktów końcowych, jak ma to miejsce u spokrewnionego strukturalnie hemu. Przełom nastąpił dopiero w 1991 roku, kiedy po raz pierwszy zidentyfikowano i w pełni scharakteryzowano bezbarwny produkt rozpadu chlorofilu Hv-NCC-1 z liści jęczmienia zwyczajnego (ang. Hordeum vulgare-nonfluorescent chlorophyll catabolite-1) [5]. Odkrycie to nadało właściwy kierunek analizom, dzięki którym na przestrzeni zaledwie trzydziestu lat poznaliśmy szczegółowy mechanizm rozkładu chlorofilu w liściach i skórkach owoców. Degradacja chlorofilu w obu organach następuje według wspólnego szlaku metabolicznego, znanego pod nazwą ścieżki oksygenazy feoforbidu $a$. Wśród końcowych produktów katabolicznych przemian chlorofilu dominują liniowe związki zwane filobilinami (ang. phyllobilins) [6]. 
W szlaku rozkładu chlorofilu wyróżnić można dwa zasadnicze etapy: wczesne, z udziałem enzymów, zlokalizowane w obrębie chloroplastu (Ryc. 1) oraz późne, głównie nieenzymatyczne, zachodzące na terenie cytozolu i wakuoli (Ryc. 2) [7]. Pierwsze reakcje, które katalizują enzymy reduktaza Chl $b$ oraz reduktaza 7-hydroksymetylochlorofilu a (ang. 7-hydroxymethylchlorophyll a reductase, HCAR) mają charakter obligatoryjny i prowadzą do przekształcenia cząsteczek Chl $b$ w Chl $a$. W kolejnym kroku białka SGR (ang. stay-green) usuwają z centrum makropierścienia $\mathrm{Chl} a$ atom magnezu [8], a specyficzna esteraza - feofitynaza (ang. Pheophytinase, PPH) odcina łańcuch fitolu powstałej cząsteczki feofityny $a$ (Feo $a)$. W skórkach dojrzewających owoców dwie powyższe reakcje zachodzą zwykle w odwrotnej kolejności. W reakcji deestryfikacji bierze wtedy udział chlorofilaza (ang. Chlorophyllase, CLH) dla której substratem oprócz cząsteczki Chl a może być także 13-hydroksychlorofil $a$ oraz bakteriochlorofil $a$. Produktem reakcji katalizowanej przez chlorofilazę jest chlorofilid (Chlid a), z którego centrum następnie usuwany jest jon $\mathrm{Mg}^{2+}$. W wyniku tych reakcji powstaje feoforbid $a$ (Feid $a$ ), ostatni produkt rozpadu chlorofilu o barwie zielonej. Związek ten ulega w kolejnym etapie przekształceniu $\mathrm{w}$ liniowy produkt na skutek dwuetapowej reakcji katalizowanej przez oksygenazę $\mathrm{PaO}$ (ang. pheophorbide a oxygenase) oraz występujące powszechnie u roślin białko RCCR (ang. red chlorophyll catabolite reductase). Rozerwanie makropierścienia feoforbidu a następuje między 4 i 5 atomem węgla, prowadząc do powstania czerwonego katabolitu chlorofilu (ang. red chlorophyll catabolite, RCC). Gdy czerwone produkty rozpadu wciąż związane są $\mathrm{z}$ enzymem $\mathrm{PaO}$, następuje redukcja podwójnego wiązania pomiędzy atomami węgla w pozycji 16/17. Liniowy produkt tej reakcji $\mathrm{w}$ postaci wczesnego fluorescencyjnego katabolitu chlorofilu (ang. primary fluorescent chlorophyll catabolite, $p$ FCC) uwalniany jest do stromy chloroplastu. Z uwagi na przerwaną ciągłość wiązań sprzężonych $\mathrm{w}$ makropierścieniu tetrapirolowym, $p$ FCC słabo absorbują $\mathrm{w}$ zakresie widzialnym. Ich fototoksyczność jest znacznie mniejsza niż feoforbidu a czy RCC, pomimo to w bardzo krótkim czasie przekształcane są w kolejne pochodne. Wyjątkiem są hiperzmodyfikowane fluorescencyjne katabolity chlorofilu (ang. hypermodified fluorescent chlorophyll catabolite, hmFCC) w skórkach dojrzałych bananów Musa acuminata [9] oraz liściach tropikalnej rośliny Spathiphyllum wallisii [10], które na skutek estryfikacji reszty kwasu propionowego w pozycji 12 znacznie wolniej ulegają dalszym przekształceniom i mogą przebywać w komórkach przez wiele godzin. Ścieżkę rozpadu na terenie chloroplastu u większości gatunków kończą reakcje hydroksylacji $p$ FCC, w których uczestniczy przypuszczalnie kompleks białek TIC55 (ang. tranclocon at the inner chloroplast envelope 55) [11]. Hydroksylowane pochodne FCC w sposób zależny od ATP eksportowane są następnie do cytozolu przez niezidentyfikowany przenośnik w błonie chloroplastu.

W cytozolu cząsteczki FCC (ang. fluorescent chlorophyll catabolite) ulegać mogą gatunkowo-specyficznym modyfikacjom grup bocznych z udziałem/bez udziału enzymów po czym trafiają do wakuoli (Ryc. 3). W komórkach Arabidopsis thaliana występują co najmniej dwa białka posiadające zdolność przenoszenia katabolitów chlorofilu przez tono-
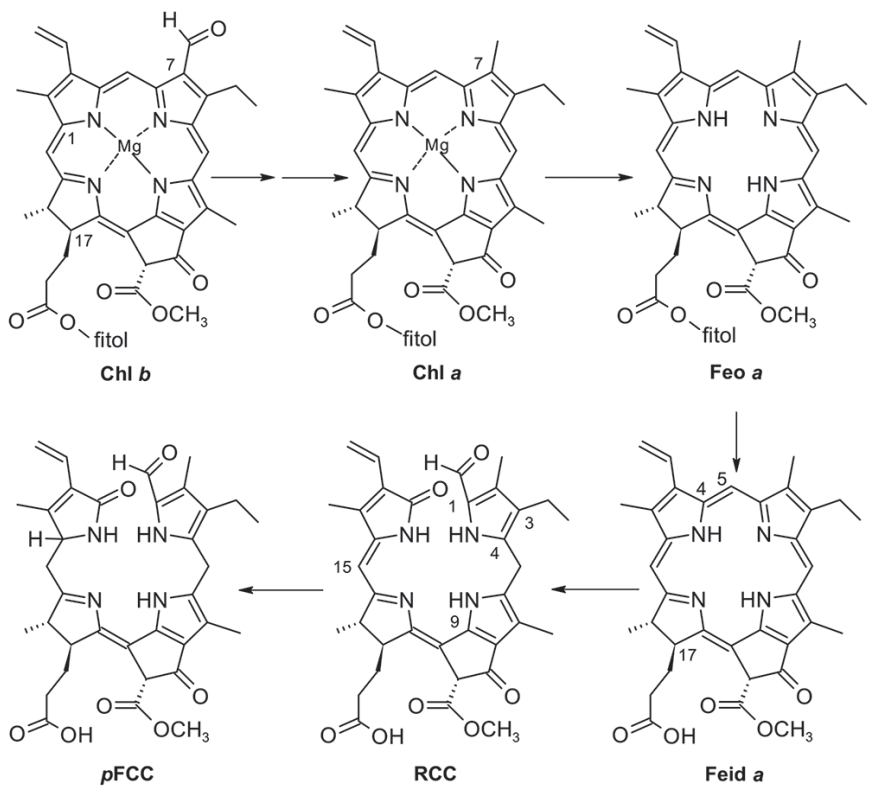

Rycina 1. Schemat najważniejszych reakcji rozkładu chlorofilu zachodzących w chloroplaście roślin wyższych. Opis w tekście. Opracowano wg [7].

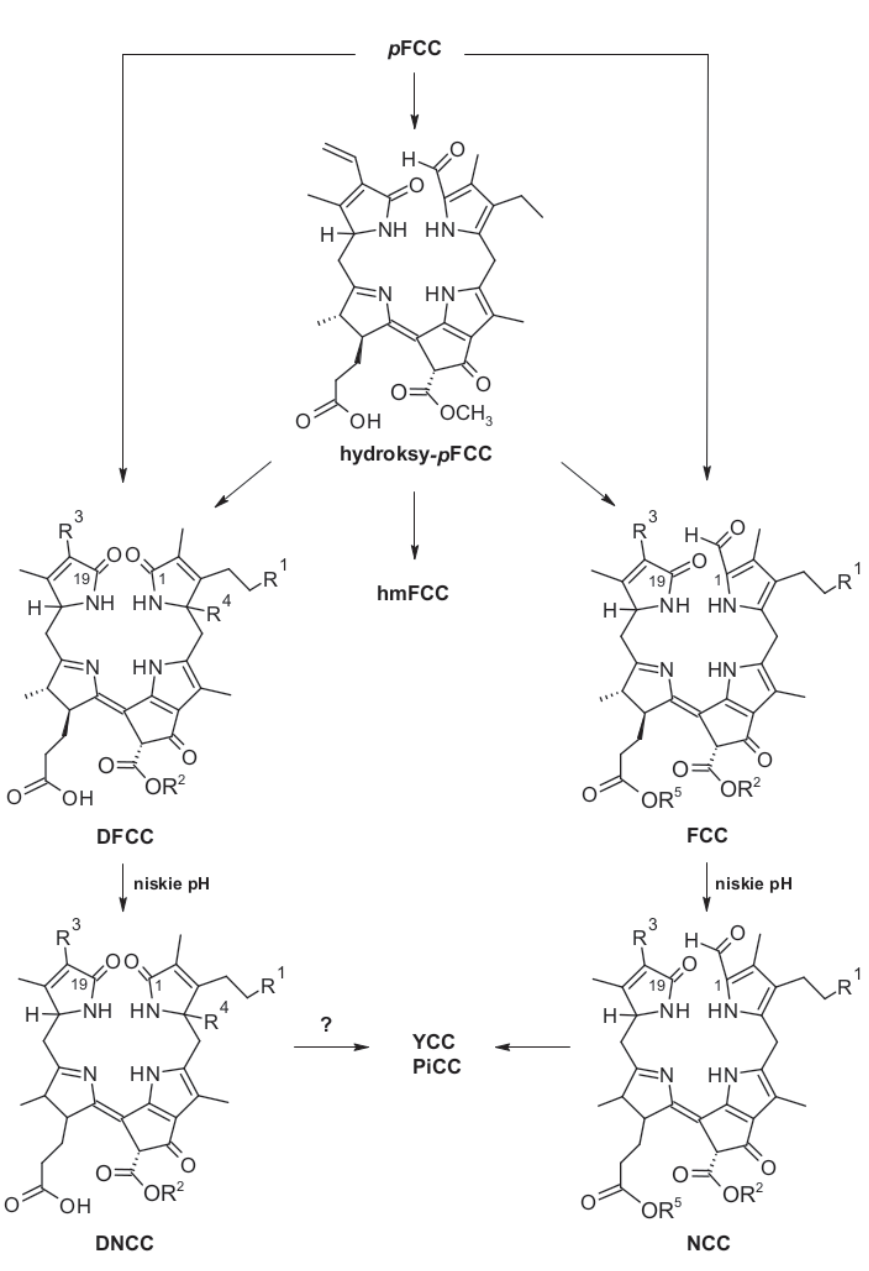

Rycina 2. Przemiany prowadzące do powstania NCC i DNCC - końcowych produktów rozkładu chlorofilu a u roślin wyższych. Dokładny spis zidentyfikowanych dotąd filobilin wraz z rodzajami podstawników oznaczonych na schemacie symbolami $\mathrm{R}^{1}-\mathrm{R}^{5}$ dostępny w odnośniku [3]. 


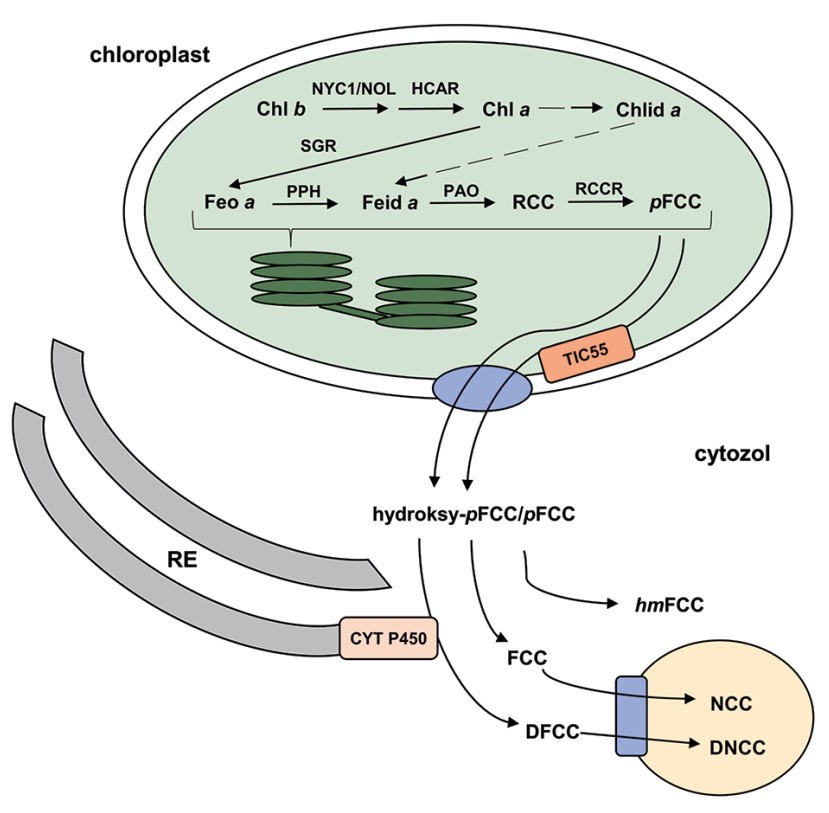

wakuola

Rycina 3. Lokalizacja komórkowa reakcji rozkładu chlorofilu. Opis w tekście. Opracowano wg $[7,11]$.

plast. Są to zależne od ATP białka przenośnikowe AtMRP2 i AtMRP3 (ang. Arabidopsis thaliana multidrug resistance-associated protein), jednak ich udział $\mathrm{w}$ transporcie produktów rozkładu chlorofilu in vivo potwierdzono dotychczas wyłącznie na drodze ekspresji genów A. thaliana w komórkach drożdży $[12,13]$.

W lekko kwaśnym środowisku wakuoli (pH 5-6) następuje izomeryzacja cząsteczek FCC w bezbarwne niefluorescencyjne katabolity (ang. nonfluorescent chlorophyll catabolite, NCC). W tkankach kilku gatunków roślin zidentyfikowano również barwne produkty degradacji chlorofilu, żółte YCC (ang. yellow chlorophyll catabolite) [14] i różowe PiCC (ang. pink chlorophyll catabolite) [15], które powstają prawdopodobnie na skutek endogennego utleniania cząsteczek NCC [16]. Wśród niefluorescencyjnych produktów degradacji chlorofilu wyróżnia się obecnie dwie grupy związków klasyfikowane jako 1-formylo-19-oksobiliny (typ I - NCC) oraz 1,19-dioksobiliny (ang. dioxobilin-type nonfluorescent chlorophyll catabolite, typ II - DNCC). Odkryte stosunkowo niedawno DNCC [17] stanowią aż $90 \%$ frakcji produktów rozpadu chlorofilu w komórkach $A$. thaliana, a w ich postawaniu uczestniczą cytochromy P450 [18].

\section{MUTACJE GENÓW ODPOWIEDZIALNYCH ZA ROZPAD CHLOROFILU U ROŚLIN WYŻSZYCH}

Chociaż katabolizm chlorofilu może być inicjowany przez szereg biotycznych i abiotycznych czynników, masowa degradacja tych barwników zachodzi głównie w starzejących się komórkach.

$\mathrm{Na}$ poziomie molekularnym $\mathrm{w}$ indukcji katabolizmu chlorofilu główną rolę odgrywają czynniki transkrypcyjne NAC i WKRY, których aktywność objawia się na różnych etapach rozwoju rośliny [19]. Zmiany aktywności tych czynników oraz mutacje sekwencji kodujących białka enzy- matyczne szlaku degradacji chlorofilu mogą prowadzić do śmierci osobnika lub ujawnienia fenotypu „stay-green”. Do mutacji letalnych należą modyfikacje genów oksydazy $\mathrm{PaO}$ i reduktazy RCCR. Przedwczesna śmierć mutantów następuje podczas żółknienia liści, głównie na skutek nagromadzenia fototoksycznych produktów pośrednich, feoforbidu $a$ i RCC $[20,21]$. Wśród genotypów nieletalnych wyróżnić można mutacje prowadzące do ujawnienia kosmetycznych oraz funkcjonalnych fenotypów "stay-green”. Osobniki o fenotypie kosmetycznym (ang. cosmetic stay-green) charakteryzuje opóźniony moment inicjacji rozpadu chlorofilu w tkankach asymilujących, podczas gdy ich aktywność fotosyntetyczna maleje podobnie, jak u szczepów dzikich. Funkcjonalne fenotypy "stay-green” cechują się znaczącym opóźnieniem inicjacji (mutanty sgr typu A) lub wydłużeniem w czasie (mutanty sgr typu B) procesu starzenia, którego rozpad chlorofilu jest tylko jednym $\mathrm{z}$ istotnych elementów [22].

Mutanty "stay-green" posiadają zwykle zmodyfikowane sekwencje kodujące białka uczestniczące $\mathrm{w}$ usuwaniu jonów $\mathrm{Mg}^{2+} \mathrm{z}$ centrum pierścienia porfirynowego oraz redukcji Chl $b$. Analizy mutantów A. thaliana i Oryza sativa, które posiadają dwa izoenzymy reduktazy Chl $b$ : NYC1 (ang. non-yellow coloring-1) i NOL (ang. nyc-1 like) wykazały, że nawet pojedyncza zmiana nukleotydu $\mathrm{w}$ ich sekwencji może prowadzić do ujawnienia fenotypu "stay-green”. Efekt fenotypowy zależny jest także od rodzaju izoformy, która u danego osobnika jest nieaktywna. Mutacja sekwencji kodującej NYC1, powoduje u A. thaliana zwiększoną retencję chlorofilu w liściach w porównaniu do szczepów dzikich, podczas gdy u O. sativa podobny skutek wywołuje jednoczesna mutacja $n y c 1$ i nol [23]. Utrzymywanie się zielonych barwników w liściach mutantów związane jest z opóźnionym odłączaniem się kompleksów antenowych LHCII, która spowalnia przemiany Chl $b$ do Chl $a$ i zmniejsza dostępność substratu dla oksygenazy $\mathrm{PaO}$. Analizy wpływu mutacji genów reduktaz Chl $b$ na przebieg rozpadu chlorofilu w nasionach $A$. thaliana wykazały natomiast, że fenotyp „stay-green” ujawnia się tylko u podwójnych mutantów nyc1/nol [24].

Rośliny „stay-green” budzą zrozumiałe zainteresowanie wśród rolników. Osobniki, które później niż szczepy dzikie tracą chlorofil, dłużej wydajnie fotosyntetyzują, zwiększając szanse na lepsze ilościowo i jakościowo plony. Ponadto niektóre tego typu mutanty wykazują zwiększoną odporność na stres suszy, co zaobserwowano u rodzaju Sorghum [25].

\section{ROZKŁAD CHLOROFILU U FOTOSYNTETYZUJĄCYCH ORGANIZMÓW WODNYCH}

W środowisku wodnym występuje ogromna różnorodność organizmów zdolnych do oksygenicznej fotosyntezy. $Z$ uwagi na zróżnicowane warunki świetlne organizmy te zajęły charakterystyczne nisze, przystosowując skład barwników asymilacyjnych dla maksymalnego wykorzystania docierającego światła. Gdy u roślin lądowych dominują cząsteczki Chl $a$ i Chl $b$, u wodnych fotoautotrofów oprócz występującego w centrach reakcji fotosystemów Chl $a$ obecne są także cząsteczki Chl $b$ (zielenice), Chl c (okrzemki, bruzdnice i brunatnice) oraz Chl $d$ (krasnorosty). Mając na uwadze fakt, że fotosyntetyzujące organizmy wodne, głównie fitoplankton, uczestniczą $\mathrm{w}$ syntezie/rozpadzie około $2 / 3$ 
rocznej puli chlorofilu na Ziemi [26], ogromne ilości metabolitów chlorofilu produkowane i uwalniane są do otoczenia podczas starzenia się populacji glonów i cyjanobakterii.

Nasza obecna wiedza o katabolizmie chlorofilu w komórkach tych organizmów opiera się głównie na analizach barwników uwalnianych do otoczenia przez starzejące się hodowle prowadzone w warunkach laboratoryjnych. Zidentyfikowane dotychczas związki zaklasyfikować można do dwóch grup: o otwartym i zamkniętym makropierścieniu tetrapirolowym.

Pierwszą grupę pochodnych chlorofilu reprezentują głównie barwne związki izolowane z pożywek hodowlanych zielenic, w tym najintensywniej badanego pod kątem katabolizmu chlorofilu gatunku Auxenochlorella protothecoides. Pierwsze doniesienia o czerwonych barwnikach, przypuszczalnych produktach degradacji chlorofilu u tego organizmu pojawiły się w latach sześćdziesiątych ubiegłego wieku $[27,28]$. Autorzy zaobserwowali, że podczas wzrostu populacji na podłożu bogatym w glukozę i ubogim w azot, zmniejsza się zawartość Chl $a$ i Chl $b$ w komórkach, czemu towarzyszy jednoczesny wzrost stężenia czerwonych barwników w medium hodowlanym. Znacznie później ustalono, że związki produkowane przez A. prothotecoides posiadają liniowe struktury zbliżone do RCC roślin wyższych. W kontraście do tego odkrycia ustalono, że tetrapirole z pożywki A. prothotecoides wywodzą się zarówno od Chl $a$ i Chl $b$ [29], podczas gdy niemal wszystkie filobiliny (za wyjątkiem jednego związku) to pochodne wyłącznie Chl $a$. Poszukiwania enzymu, który mógłby bezpośrednio uczestniczyć w powstawaniu tych produktów rozpadu nie przyniosły jednoznacznej odpowiedzi. Analizy porównawcze sekwencji kodujących oksydazę $\mathrm{PaO}$ A. thaliana i najbardziej zbliżonego aktywnością do niej enzymu $A$. prothotecoides wykazały zaledwie $31 \%$ podobieństwo, podczas gdy między gatunkami lądowymi obserwuje się około $70 \%$ zgodność sekwencji oksydazy [30]. W ostatnim latach na podstawie analiz genomu potwierdzono, że białko RCCR u A. prothotecoides nie występuje [30]. W medium pohodowlanym zielenicy nie zidentyfikowano także obecności produktów przemian chlorofilu podobnych do roślinnych FCC czy NCC, co sugeruje, że rozpad chlorofilu u tego gatunku kończy się na etapie liniowych, czerwonych pochodnych, które uwalniane są następnie do otoczenia.

Informacje o kolejnej grupie czerwonych pochodnych chlorofilu dostarczył zespół Doi [31]. W badaniach wykorzystano odżywiające się miksotroficznie hodowle mutanta Chlamydomonas reinhardtii nieprodukującego $\mathrm{Chl} b$, które po kilku dniach wzrostu na świetle przenoszono do ciemności, aby przyspieszyć w komórkach rozpad chlorofilu. W mieszaninie czerwonych barwników, które wyizolowano z pożywki i analizowano za pomocą techniki RP-HPLC (ang. reverse phase-high performance liquid chromatography) dominował związek o symbolu P535, produkt rozpadu Chl $a$ o otwartym pierścieniu. Kontynuacją tych doświadczeń były analizy wpływu dostępności tlenu na rodzaj produktów degradacji chlorofilu. Zaobserwowano, że udział liniowego tetrapirolu P535 w mieszaninie barwników był zdecydowanie większy w hodowlach o nieograniczonym dostępie do tlenu, podczas gdy w warunkach beztlenowych w pożyw-
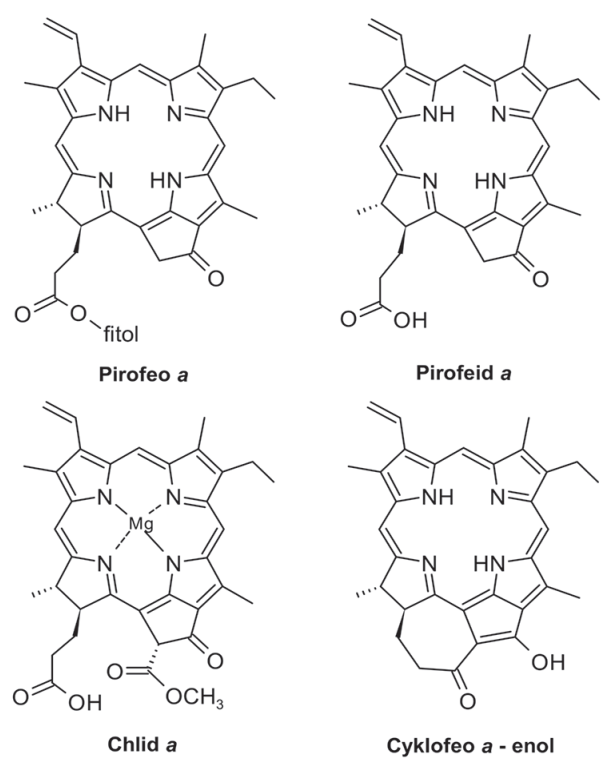

Rycina 4. Struktury chemiczne wybranych produktów degradacji chlorofilu.

kach dominowały pochodne o zamkniętym makropierścieniu, m.in. chlorofilid $a$ (Ryc. 4), feoforbid $a$ oraz pirofeoforbid $a$ (Pirofeid a) (Ryc. 4), który występował najobficiej [32]. Najnowsze analizy związków uwalnianych do podłoża hodowlanego przez starzejące się komórki szczepu dzikiego C. reinhardtii (cc1690) pokazują, że czerwone barwniki opisane w pracy Doi i wsp. (1997) to nie jedyne katabolity chlorofilu u tego gatunku. Z wykorzystaniem techniki spektrometrii masowej zidentyfikowano ostatnio grupę liniowych pochodnych chlorofilu o żółtej barwie (Zalewska i wsp., wyniki nieopublikowane).

Czerwone produkty rozkładu chlorofilu zidentyfikowano także w pożywce pohodowlanej zielenicy planktonowej Desmodesmus subspicatus [33]. Różniące się nieznacznie wzorem sumarycznym związki, były uwalniane do medium hodowlanego głównie podczas fazy stacjonarnej wzrostu populacji glonów. Do dziś, tak jak w przypadku liniowych katabolitów chlorofilu C. reinhardtii, nie poznaliśmy jednak ich dokładnej struktury chemicznej.

Obecność kilku produktów rozkładu chlorofilu o zamkniętym makropierścieniu pirolowym potwierdzono $\mathrm{w}$ adaptowanej do ciemności hodowli Euglena gracilis oraz kokulturach bakterii morskich i dwóch gatunków glonów: okrzemki Chaetoceros gracilis i eustigmatofitu Nannochloropsis oculata. W ekstrakcie barwników z komórek E. gracilis dominowały dwie pochodne chlorofilu - feofityna oraz pirofeofityna a (Pirofeo a) (Ryc. 4) [34]. W hodowli C. gracilis i N. oculata potwierdzono natomiast występowanie wczesnych pochodnych chlorofilu: allomerów i epimerów Chl $a$, chlorofilidu $a$ oraz feofityny $a$, a także drugorzędowych produktów degradacji chlorofilu: feoforbidu $a$, pirofeoforbidu $a$, pirofeofityny $a$ oraz sterylowych estrów chloryny [35]. W analogicznie prowadzonych hodowlach kontrolnych struktury pozbawione reszty karboksymetylowej (pirofeofityna i pirofeoforbid $a$ ) nie zostały zidentyfikowane, co wskazuje na bezpośredni udział bakterii w powstawaniu tych związków. 
Jedną z najstarszych grup organizmów przeprowadzających oksygeniczną fotosyntezę są cyjanobakterie. Kluczowym barwnikiem asymilacyjnym, umożliwiającym prawidłowy przebieg pierwotnych reakcji fotosyntezy u tych prokariontów jest chlorofil. W luźno ułożonych w cytoplazmie tylakoidach cyjanobakterii występuje zwykle tylko Chl $a$. Nieliczne gatunki posiadają dodatkowo $\mathrm{Chl} b$ (przedstawiciele rodzaju Prochloron), Chl $d$ (Acaryochloris marina) lub Chl $f$ (Halomicronema hongdechloris i szczep KC1 z jeziora Biwa). W przeciwieństwie do ogromu uwagi, którą poświęcono na poznanie przebiegu i mechanizmów regulacji biosyntezy barwników chlorofilowych u tych organizmów [36], bardzo niewiele wiadomo o tym jak przebiega ich degradacja. Jednym $\mathrm{z}$ niewielu badanych pod tym kątem gatunków jest Synechocystis sp. PCC 6803. W pełni zsekwencjonowany genom tej cyjanobakterii czyni ją idealnym modelem m.in. do badań genetycznych uwarunkowań procesu fotosyntezy. Dotychczasowe eksperymenty z wykorzystaniem mutantów tego szczepu, pozbawionych jednego lub obu fotosystemów, potwierdziły występowanie produktów degradacji chlorofilu o zamkniętym łańcuchu, a mianowicie chlorofilidu i feoforbidu $a$ [37]. Dzięki zastosowaniu metody znakowania związków izotopem azotu ${ }^{15} \mathrm{~N}$ i węgla ${ }^{13} \mathrm{C}$ wykazano, że zatrzymanie rozpadu chlorofilu na etapie wczesnych pochodnych u tego szczepu, prowadziło do resyntezy funkcjonalnego Chl a z wolnych cząsteczek chlorofilidu i fitolu przy udziale kinazy SLR1652 [38].

W środowisku wodnym liczną grupę produktów rozpadu chlorofilu stanowią związki powstałe na drodze trawienia fitopikoplanktonu przez heterotroficzne Protista. Detoksykacja chlorofilu w układzie pokarmowym tych organizmów następuje na skutek przekształcania zielonych barwników w enolową formę cyklofeoforbidu a (Cyklofeid $a$-enol) (Ryc. 4) [39]. Takie związki nie absorbują światła w zakresie widzialnym, a tym samym nie uczestniczą $\mathrm{w}$ powstawaniu reaktywnych form tlenu. Jednak roślinożerne Protista nie odżywiają się glonami jednokomórkowymi o względnie dużej wielkości, a zwłaszcza glonami wielokomórkowymi. Jak zatem przebiega proces degradacji chlorofilu u tych organizmów? Brak jest nadal odpowiedzi na to i szereg innych pytań m.in. dotyczących lokalizacji i regulacji przemian chlorofilu. Otwartą kwestią pozostaje także, czy produkty rozpadu chlorofilu uwalniane są do otoczenia na skutek obumierania i rozpadu komórek, czy też istnieje specyficzny mechanizm ich wydzielania, jak sugerują autorzy kilku przytoczonych powyżej prac.

Jednym z głównych celów badawczych, które pozwoliłyby odpowiedzieć na powyższe pytania jest dokładne ustalenie udziału enzymów w przemianach chlorofilu u wodnych fotoautotrofów. Do tej pory potwierdzono aktywność komórkową zaledwie kilku białek enzymatycznych uczestniczących w rozkładzie chlorofilu, m.in. chlorofilazy, występującej u wszystkich eukariotycznych glonów [40] oraz enzymu usuwającego resztę metoksykarbonylową feoforbidu a zielenicy C. reinhardtii [32]. Na drodze ekspresji genów $\mathrm{w}$ komórkach $A$. thaliana potwierdzono także aktywność katalityczną Mg-dechelatazy CrSGR występującej natywnie u C. reinhardtii [41].
Analizy genomu wybranych gatunków glonów i cyjanobakterii potwierdziły obecność sekwencji kodujących białka o dużej homologii z roślinną oksygenazą $\mathrm{PaO}$ m.in. reduktazy feoforbidu kodowanej przez gen slr1747 Synechocystis sp. PCC 6803 [42] oraz trzech homologów pao1-3 w komórkach C. reinhardtii. W odróżnieniu od eukariotycznych glonów, w genomach cyjanobakterii powszechnie występują także homologi reduktazy RCC. Wciąż brakuje dowodów, które potwierdziłyby, że produkty ekspresji tych genów to enzymy aktywne in vivo.

W przeciwieństwie do wysoce konserwowanych fragmentów kodujących białka SGR, HCAR, PPH, PaO i RCCR roślin lądowych, podobieństwo ich sekwencji maleje im niższej ewolucyjnie znajduje się badany organizm fotosyntetyzujący [3]. Konsekwencją mniejszej homologii białek degradujących chlorofile wśród poszczególnych taksonów wodnych fotoautotrofów może być znacznie bardziej zróżnicowany niż u roślin lądowych mechanizm rozkładu barwników chlorofilowych.

\section{ROLA ROZKŁADU CHLOROFILU I JEGO POCHODNYCH W ONTOGENEZIE ROŚLIN I GLONÓW}

Warunkiem skutecznej ochrony starzejących się tkanek przed toksycznym działaniem wolnych cząsteczek chlorofilu jest proces ich szybkiej degradacji. Głównym argumentem, potwierdzającym nadrzędny antyoksydacyjny charakter tego procesu jest fakt, że skomplikowane, wieloetapowe przemiany chlorofilu prowadzą ostatecznie do pochodnych, o znikomych zdolnościach absorpcyjnych w pasmie bliskiego ultrafioletu. Dodatkowo, czas półtrwania produktów rozkładu poprzedzających liniowe katabolity $p$ FCC jest bardzo krótki, dzięki czemu fototoksyczne pochodne nie ulegają nagromadzeniu $\mathrm{w}$ starzejących się chloroplastach. Końcowe produkty rozpadu chlorofilu takie jak YCC i NCC, wykazujące silne działanie antyoksydacyjne, mogą stanowić także dodatkowy czynnik ochrony wewnątrzkomórkowej przed reaktywnymi formami tlenu, powstającymi na skutek transferu energii wzbudzenia wolnego chlorofilu na tlen cząsteczkowy.

Pozostałe produkty rozkładu chlorofilu wykazują także szereg interesujących właściwości. Wzbudzone cząsteczki FCC mogą brać udział w tworzeniu tlenu singletowego, potencjalnego elementu sygnalizacji stresu komórkowego oraz obrony przed atakiem patogenów [43]. Barwne końcowe produkty rozpadu PiCC, tworzące przejściowe kompleksy $\mathrm{z}$ metalami na drugim stopniu utlenienia, m.in. $\mathrm{Zn}, \mathrm{Cd}, \mathrm{Ni}$, $\mathrm{Cu}, \mathrm{Pd}$, mogą być rozpatrywane jako ważny element mechanizmów sekwestracji metali ciężkich $\mathrm{w}$ roślinach z grupy hiperakumulatorów [6].

Rozkład chlorofilu odgrywa także ważną rolę w remobilizacji składników odżywczych i budulcowych, głównie zredukowanych form azotu i jonów magnezu. Wbrew wcześniejszym teoriom odzysk azotu nie dotyczy atomów tego pierwiastka występującego $\mathrm{w}$ strukturze chlorofilu, lecz białek chloroplastowych. Podczas rozpadu chlorofilu, zielone barwniki stopniowo uwalniane są z anten oraz centrów reakcji fotosystemów. Powoduje to destabilizację komplek- 
sów białkowo-barwnikowych oraz ułatwia późniejszą proteolizę uwolnionych białek [44]. Aminokwasy pochodzące $\mathrm{z}$ ich rozkładu po przetransportowaniu do odpowiednich organów, mogą posłużyć roślinie jako rezerwuar związków azotu w kolejnym sezonie wegetacji.

Aspekt antyoksydacyjny katabolizmu chlorofilu wydaje się odgrywać dużo mniejsze znaczenie w komórkach wodnych fotoautotrofów niż u roślin lądowych. Biorąc pod uwagę stosunkowo krótki cykl życia glonów i cyjanobakterii oraz większą stabilność warunków panujących w środowisku wodnym, przekształcanie chlorofilu do związków w których ciągłość pierścienia porfirynowego jest zachowana, wydaje się stanowić lepszą strategię adaptacyjną niż wykształcenie energetycznie kosztownego, wieloetapowego szlaku rozkładu chlorofilu do liniowych pochodnych.

\section{PRODUKTY METABOLIZMU CHLOROFILU JAKO POTENCJALNE ELEMENTY LUDZKIEJ TERAPII ANTYNOWOTWOROWEJ}

Chlorofile i ich pochodne znalazły szerokie zastosowanie jako barwniki kosmetyczne i spożywcze (E140-chlorofil, E141-chlorofilina, czyli sól sodowo-miedziowa chlorofilu), związki pochłaniające zapachy, substancje o działaniu przeciwzapalnym czy przeciwwirusowym. Prowadzone są również analizy mające na celu oszacowanie opłacalności produkcji ogniw fotowoltaicznych, w których konwersja energii słonecznej $w$ energię elektryczną zachodzi dzięki barwnikom chlorofilowym, czy też indukowanej światłem produkcji biopaliwa wodorowego [45].

Ze względu na wysoką toksyczność w obecności światła $\mathrm{w}$ ostatnich latach chlorofile i ich metabolity intensywnie badane są pod kątem użyteczności w terapii fotodynamicznej (ang. photodynamic theraphy, PDT). Silną aktywność hamującą proliferację komórek nowotworowych wykazują feofityna i feoforbid a/b oraz (pół)syntetyczne związki oparte na ich strukturach. Wybrane produkty degradacji chlorofilu oraz funkcjonalne barwniki mogą znaleźć potencjalne zastosowanie m.in. w terapii nowotworów piersi [46] i wątroby $[47,48]$.

\section{PIŚMIENNICTWO:}

1. Hendry GA, Houghton JD, Brown SB (1987) The degradation of chlorophyll - a biological enigma. New Phytol 107: 255-302

2. Grimm B, Porra RJ, Rüdiger W, Scheer H (2006) Chlorophylls and bacteriochlorophylls. Vol. 25 of Advances in Photosynthesis and Respiration, Springer, Berlin, Heidelberg, New York

3. Kuai B, Chen J, Hörtensteiner S (2018) The biochemistry and molecular biology of chlorophyll breakdown. J Exp Bot 69: 751-767

4. Field CB, Behrenfield MJ, Randerson JT, Falkowski P (1998) Primary production of the biosphere: integrating terrestrial and oceanic components. Science 281: 237-240

5. Kräutler B, Jaun B, Bortlik KH, Schellenberg M, Matile P (1991) On the enigma of chlorophyll degradation: the constitution of a secoporphinoid catabolite. Angew Chem Int Ed Engl 30: 1315-1318

6. Kräutler B (2016) Breakdown of chlorophyll in higher plants - phyllobilins as abundant, yet hardly visible signs of ripening, senescence, and cell death. Angew Chem Int Ed Engl 55: 4882-4907

7. Hörtensteiner S, Kräutler B (2011) Chlorophyll breakdown in higher plants. BBA - Bioenergetics 1807: 977-988
8. Shimoda M, Ito H, Tanaka A (2016) Arabidopsis STAY-GREEN, Mendel's green cotyledon gene, encodes magnesium-dechelatase. Plant Cell 28: 2147-2160

9. Moser S, Müller T, Holzinger A, Lütz C Kräutler B (2012) Structures of chlorophyll catabolites in bananas (Musa acuminata) reveal a split path of chlorophyll breakdown in a ripening fruit. Chem Eur J 18: $10873-$ 10885

10. Kräutler B, Banala S, Moser S, Vergeiner C, Müller T, Lütz C, Holzinger A (2010) A novel blue fluorescent chlorophyll catabolite accumulates in senescent leaves of the peace lily and indicates a split path of chlorophyll breakdown. FEBS Lett 584: 4215-4221

11. Hauenstein M, Christ B, Das A, Aubry S, Hörtensteiner S (2016) A Role for TIC55 as a hydroxylase of phyllobilins, the products of chlorophyll breakdown during plant senescence. Plant Cell 28: 2510-2527

12. Lu YP, Li ZS, Drozdowicz YM, Hörtensteiner S, Martinoia E, Rea PA (1998) AtMRP2, an Arabidopsis ATP binding cassette transporter able to transport glutathione S-conjugates and chlorophyll catabolites: functional comparisons with AtMRP1. Plant Cell 10: 267-282

13. Tommasini R, Vogt E, Fromenteau M, Hortensteiner S, Matile P, Amrhein N, Martinoia E (1998) An ABC-transporter of Arabidopsis thaliana has both glutathione-conjugate and chlorophyll catabolite transport activity. Plant J 13: 773-780

14. Moser S, Ulrich M, Müller T, Kräutler B (2008) A yellow chlorophyll catabolite is a pigment of the fall colours. Photochem Photobiol Sci 7:1577-1581

15. Ulrich M, Moser S, Müller T, Kräutler B (2011) How the Colourless 'Nonfluorescent' Chlorophyll Catabolites Rust. Chem Eur J 17: 23302334

16. Vergeiner C, Ulrich M, Li C, Liu X, Müller T, Kräutler B (2015) Stereo and regioselective phyllobilane oxidation in leaf homogenates of the peace lily (Spathiphyllum wallisii): hypothetical endogenous path to yellow chlorophyll catabolites. Chem Eur J 21: 136-149

17. Müller T, Rafelsberger M, Vergeiner C, Kräutler B (2011) A dioxobilane as product of a divergent path of chlorophyll breakdown in norway maple. Angew Chem Int Ed 50: 10724-10727

18. Christ B, Süssenbacher I, Moser S, Bichsel N, Egert A, Müller T, Kräutler B, Hörtensteiner S (2013) Cytochrome P450 CYP89A9 is involved in the formation of major chlorophyll catabolites during leaf senescence in Arabidopsis. Plant Cell 25: 1868-1880

19. Kusaba M, Tanaka A, Tanaka R (2013) Stay-green plants: what do they tell us about the molecular mechanism of leaf senescence. Photosynth Res 117: 221-234

20. Pružinská A, Anders I, Tanner G, Roca M, Hörtensteiner S (2003) Chlorophyll breakdown: pheophorbide a oxygenase is a Rieske-type iron-sulfur protein, encoded by the accelerated cell death 1 gene. Proc Natl Acad Sci USA 100: 15259-15264

21. Pružinská A, Anders I, Aubry S, Schenk N, Tapernoux-Lüthi E, Müller T, Kräutler B, Hörtensteiner S (2007) In vivo participation of red chlorophyll catabolite reductase in chlorophyll breakdown. Plant Cell 19: 369-387

22. Thomas H, Ougham H (2014) The stay-green trait. J Exp Bot 65: 38893900

23. Jibran R, Sullivan KL, Crowhurst R, Erridge ZA, Chagné D, McLachlan AR, Brummell DA, Dijkwel PP, Hunter DA (2015) Staying green postharvest: how three mutations in the Arabidopsis chlorophyll b reductase gene NYC1 delay degreening by distinct mechanisms. J Exp Bot 66: 6849-6862

24. Nakajima S, Ito H, Tanaka R, Tanaka A (2012) Chlorophyll b reductase plays an essential role in maturation and storability of Arabidopsis seeds. Plant Physiol 160: 261-273

25. Borrell AK, Mullet JE, George-Jaeggli B, van Oosterom EJ, Hammer GL, Klein PE, Jordan DR (2014) Drought adaptation of stay-green sorghum is associated with canopy development, leaf anatomy, root growth, and water uptake. J Exp Bot 65: 6251-6263

26. Rüdiger W (1997) Chlorophyll metabolism: From outer space down to the molecular level. Phytochemistry 46: 1151-1167 
27. Oshio Y, Hase E (1969) Studies on red pigments excreted by cells of Chlorella protothecoides during the process of bleaching induced by glucose or acetate. I. Chemical properties of the red pigments. Plant Cell Physiol 10: 41-49

28. Oshio Y, Hase E (1969) Studies on red pigments excreted by cells of Chlorella protothecoides during the process of bleaching induced by glucose or acetate. II. Mode of formation of the red pigments. Plant Cell Physiol 10: 51-59

29. Iturraspe J, Engel N, Gosssauer A (1994) Chlorophyll catabolism. Isolation and structure elucidation of chlorophyll $b$ catabolites in Chlorella protothecoides. Phytochemistry 35: 1387-1390

30. Gao CF, Wang Y, Shen Y, Yan D, He X, Dai JB, Wu QY (2014) Oil accumulation mechanisms of the oleaginous microalga Chlorella protothecoides revealed through its genome, transcriptomes, and proteomes. BMC Genomics 15: 582

31. Doi M, Shima S, Egashira T, Nakamura K, Okayama S (1997) New bile pigment excreted by a Chlamydomonas reinhardtii mutant: A possible breakdown catabolite of chlorophyll a. J Plant Physiol 150: 504-508

32. Doi M, Inage T, Shioi Y (2001) Chlorophyll degradation in a Chlamydomonas reinhardtii mutant: an accumulation of pyropheophorbide a by anaerobiosis. Plant Cell Physiol 42: 469-474

33. Grabski K, Baranowski N, Skórko-Glonek J, Tukaj Z (2016) Chlorophyll catabolites in conditioned media of green microalga Desmodesmus subspicatus. J Appl Phycol 28: 889-896

34. Schoch S, Scheer H, Schiff JA, Rüdiger W, Siegelman HW (1981) Pyropheophytin a accompanies pheophytin a in darkened light-grown cells of Euglena. Z Naturforsch 36c: 827-833

35. Szymczak-Żyła M, Kowalewska G (2008) The influence of microorganisms on chlorophyll a degradation in the marine environment. Limnol Oceanogr 53:851-862

36. Fujita Y, Tsujimoto R, Aoki R (2015) Evolutionary aspects and regulation of tetrapyrrole biosynthesis in cyanobacteria under aerobic and anaerobic environments. Life 5: 1172-1203

37. Vavilin D, Brune DC, Vermaas W (2005) 15N-labeling to determine chlorophyll synthesis and degradation in Synechocystis sp. PCC 6803 strains lacking one or both photosystems. Biochim Biophys Acta 1708: 91-101

38. Vavilin D, Vermaas W (2007) Continuous chlorophyll degradation accompanied by chlorophyllide and phytol reutilization for chlorophyll synthesis in Synechocystis sp. PCC 6803. Biochim Biophys Acta 1768: 920-929

39. Kashiyama Y, Yokoyama A, Kinoshita Y, Shoji S, Miyashiya H, Shiratori $\mathrm{T}$, Suga $\mathrm{H}$, Ishikawa K, Ishikawa A, Inouye I, Ishida K, Fujinuma D, Aoki K, Kobayashi M, Nomoto S, Mizoguchi T, Tamiaki H (2012) Ubiquity and quantitative significance of detoxification catabolism of chlorophyll associated with protistan herbivory. Proc Natl Acad Sci USA 109: 17328-17335

40. Barrett J, Jeffrey SW (1964) Chlorophyllase and formation of an atypical chlorophyllide in marine algae. Plant Physiol 39: 44-47

41. Matsuda K, Shimoda Y, Tanaka A, Ito H (2016) Chlorophyll a is a favorable substrate for Chlamydomonas Mg-dechelatase encoded by STAY-GREEN. Plant Physiol Bioch 109: 365-373

42. Gray J, Wardzala E, Yang ML, Reinbothe S, Haller S, Pauli F (2004) A small family of LLS1-related non-heme oxygenases in plants with an origin amongst oxygenic photosynthesizers. Plant Mol Biol 54: 39-54

43. Jockusch S, Turro NJ, Banala S, Kräutler B (2014) Photochemical studies of a fluorescent chlorophyll catabolite - source of bright blue fluorescence in plant tissue and efficient sensitizer of singlet oxygen. Photochem Photobiol Sci 13: 407-411

44. Hörtensteiner S (2009) Stay-green regulates chlorophyll and chlorophyll-binding protein degradation during senescence. Trends Plant Sci 14: 155-162

45. Ryan AA, Senge MO (2015) How green is green chemistry? Chlorophylls as a bioresource from biorefineries and their commercial potential in medicine and photovoltaics. Photochem Photobiol Sci 14: 638 660

46. Hoi SW, Wong HM, Chan JY, Yue GG, Tse GM, Law BK, Fong WP, Fung KP (2012) Photodynamic therapy of Pheophorbide a inhibits the proliferation of human breast tumour via both caspase-dependent and -independent apoptotic pathways in in vitro and in vivo models. Phytother Res 26: 734-742

47. Zhang XH, Zhang LJ, Sun JJ, Yan YJ, Zhang LX, Chen N, Chen ZL (2016) Photodynamic efficiency of a chlorophyll-a derivative in vitro and in vivo. Biomed Pharmacother 81: 265-272

48. Li WT, Tsao HW, Chen YY, Cheng SW, Hsu YC (2007) A study on the photodynamic properties of chlorophyll derivatives using human hepatocellular carcinoma cells. Photochem Photobiol Sci 6: 1341-1348

\title{
Biochemical and physiological aspects of chlorophyll breakdown
}

\section{Martyna Zalewska ${ }^{\varpi}$, Zbigniew Tukaj}

Department of Plant Physiology and Biotechnology, Faculty of Biology, University of Gdańsk, 59 Wita Stwosza St., 80-308 Gdańsk, Poland

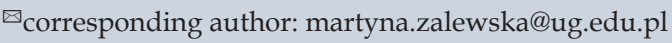

Kew words: chlorophyll, chlorophyll breakdown, chlorophyll catabolites, higher plants, phytoplankton

\begin{abstract}
During leaf senescence and fruit ripening chlorophyll is broken down into nonfluorescent catabolites (NCCs). The chlorophyll degradation pathway includes a series of biochemical transformations ocurring sequentially in chloroplasts, cytosol and vacuoles. The path begins with enzymatic reduction of chlorophyll $b$ to chlorophyll $a$. Next, the specific dechelatase and esterase remove the magnesium atom and the phytol chain resulting in the formation of pheophorbide $a$. In the next step, the porphyrin macroring is opened by pheophorbide $a$ oxygenase and red catabolite reductase. The product of this transformation is an early fluorescent catabolite $(p$ FCC), which after hydroxylation and species-specific modifications is imported into the vacuole. In acidic medium of the vacuole $p$ FCC undergo isomerization to their respective colorless NCCs, which are final chlorophyll degradation products in higher plants. There are still no answers to a number of questions about the fate and significance of millions tons of chlorophyll catabolites released annually in the aquatic environment as a result of cellular senescence and death of phytoplankton. A few reports indicate that algae and cyanobacteria may metabolize their photosynthetic pigments in a similar way as higher plants do, however, the course of chlorophyll breakdown in these organisms has not been yet elucidated.
\end{abstract}

